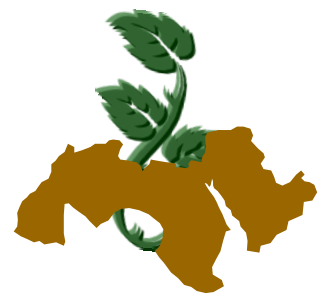

213

Arab Univ.

J. Agric. Sci., Ain Shams Univ., Cairo, 18(1), 213-219, 2010

\title{
SOME FACTORS AFFECTING SUCCESSFUL APIS MELLIFERA QUEEN REARING IN SOHAG
}

\author{
Nageh, S.M. Omran ${ }^{1}$; M.S.O. Mabrouk ${ }^{2}$ and K.M. Mohanna ${ }^{3}$ \\ 1- Plant Protection Dept., Faculty of Agric., Sohag Univ., Sohag, Egypt \\ 2- Beekeeping Res., Dept., Plant Protection Res. Institute, Agric. Res. Center, Dokki, Egypt \\ 3- Plant Protection Dept., Faculty of Agric., South Valley Univ., Qena, Egypt
}

Keywords: Honey bee, Apis mellifera, L., Queen rearing, Virgin queens, Queen production

\section{ABSTRACT}

Studies were accomplished to identify the important factors affecting successful virgin queens production in Sohag during 2007 and 2008 years. In order to find out the best teaching for rearing virgin queens by grafting method. Markedly differences in the mean number of virgin queens between single and double grafting methods, specially in spring and autumn seasons; in spring mean number of accepted cells of 43.77 with 37.66 emerged queens and 49.85 with 47.07 emerged queens were obtained when single and double grafting were used methods respectively. Spring season was favorable for queens rearing, followed by autumn and summer, while winter season came the latest. There was a clear relationship between larval age at grafting and the larval acceptance, one day old worker larvae gave the highest number of virgin queens emerged. On the other hand, the queen must be removed outside the hive 48 hrs before starting larval grafting to obtain the highest numbers of accepted queen cells. In general, double grafting, situating the cell cups frame in the hive center of the hive and fitting the cell cups on the top and bottom bar, gave the best method for queens acceptance and queens production. However, cell cups fitted on the edges of the bars were successfully reared when ambient temperatures were high in spring season, but queen cells in the center of the hive's brood nest were correlated with higher temperature and had a greater chance for emergence.

(Received July 22, 2009)

(Accepted December 19, 2009)

\section{INTRODUCTION}

Queens rearing is one of the major objects of apiaries especially for the commercial beekeepers, and it is a main factor in beekeeping (Morse, 1994). Mass production of the queens depends on large population of bees and technical procedure for guide lines to produce good queens. Rearing honeybee queens occurs when the colony is in the process of swarming, supersedure or when the queen has been accidentally lost or killed (Seeley, 1985). In all these cases, adult worker rear new queens from worker larvae that are less than $48 \mathrm{~h}$. old (Haydak, 1943). found that in Turkey the highest larvae acceptance rates were observed after dry in July and grafting with addition of royal jelly in both July and August. The highest number of queen cells were achieved using of royal jelly in July and August (Genc, et al 2005). Queen bees can be reared in the Aegean Region in Turkey from the end of March to September, but better quality of produced queens was obtained from the end of March until the end of April, (Koc and Karacaoglu, 2004) In Egypt, the acceptance and the ratio of queen emergence were the highest using royal jelly as the grafting substrate. (El-Din, 1999) Some of the Egyptian commercial queen rearers used grafting to start and rear queens. At present, grafting is the most convenient and economical method. Doolittle, (1888) devolved a method of transferring very young larvae from worker cells to specially prepared queen cell cups. Several improvements have been incorporated into Doolitlle's grafting methods. This method has been challenged as producing queens of quality inferior to those produced from the egg. Researchers have produced queens from eggs; however, no convenient and economical method has been developed. 
The acceptance of one and two day old worker larvae in upper and lower bars of the grafting frames were studied

Consequently, the aim of the present work to evaluate the effect of the seasons, location of grafting frame inside the experimental honeybee colons and location of cell cups on the grafting bar for queen production.

\section{MATERIALS AND METHODS}

Experiments were conducted in the apiary of faculty of Agriculture, Sohag university, and started on the first of January 2007, by 54 using selected colonies of the first hybrid carniolan honeybees (Apis mellifera carnica) were selected amongst the colonies of the experimental apiary in Sohag Agriculture collage, the following points were done:

\section{1- Initial preparation of the colonies for brood rearing}

In the first season (2007), strong queen-right colonies were selected, each was supplied with $50 \%$ sugar syrup, pollen substitute (cakes of soybean flour + brewer's yeast + honey) (Mohanna, 1977), combs of sealed brood just before emerging adult beginning to workers and comb of honey and pollen. Such procedure should be done two months before starting queen rearing, at which the colonies should be reached their maximum strength, having three combs of honey and pollen and five combs of sealed brood and enough of food, as well as proportional numbers of all physiological age groups of workers covering the combs (Gloria et al 1993). This procedure enables queen cells to be started and completed, in the same colony.

\section{2- Method of queen rearing}

Ten strength queen-right colonies were used to provide the experimental colonies with adult worker bees and sealed brood combs when needed. Doolittle grafting method was applied by using one, two and three day's worker, it is important to notice that queens of the experimental colonies were removed 12, 24 and 48 hours before starting grafting process.

\section{3- Production of virgin queens}

Three trails were applied as followings.

\section{3-1- Effect of rearing season}

In spring 2007, (24) experimental colonies were chosen to divided and three groups; the first was divided into two sub-groups each consisted of three colonies the first subgroup was made by one single grafting and other was made with double grafting. The second group was divided into three sub-groups having nine colonies, the queens of these colonies were removed 12, 24 and 48 hours before starting the experiment, respectively, third group was divided also into three sub-groups each having three colonies, These sub groups were provided with one, two and three day old larvae, respectively.

On the other hand, a cell cups on frame comb contain three bars, each holds 20 wax cell cups in each bar, with total 60 cell cups for each frame comb the same procedure was repeated in summer, autumn and winter.

\section{3-2- Effect of cell cups frame location inside the hive}

For this pure pose, 30 colonies were selected and divided into three groups, single and double grafting were carried out of the three groups, each group was divided into two subgroups A1, A2, B1, $\mathrm{B} 2$ and $\mathrm{C} 1, \mathrm{C} 2$ having 5 colonies, respectively. At the same time, Group A1 provided with frame contained 3 cell bars with single grafting located near the hive entrance, B1 located in the hive center and $\mathrm{C} 1$ located in the offer side of hive entrance, while A2, provided with frame contain 3 cell cup bars located near the hive entrance with double grafted, B2 located in the center and C2 placed in the offer side of hive entrance.

\section{3-3- Effect of the cell cups location on for the bar of the frame}

According to the guide numbers of virgin queens emerged in the first and second experiment and the observations of the above trials, the third experiment was conducted by selecting, 30 colonies which were divided into three groups, (10 colonies each), Each group was divided into two groups, the first group grafted with one day old larvae, single grafted, while the second also grafted with one day old larvae, double grafted. At the same time, cell cups fitted on each bar divided to five locations 1, 2, 3, 4 and 5 each of 4 cell cubs and fixed with consequent on the bar, location 1 (cell cubs fixed in the front edge), 2 (fixed by near 
the front edge), 3 (fixed on the bar center), 4 (fixed near the back edge) and 5 (fixed in the back edge). After grafting success and grafted bee cell once, the number of accepted cells were counted and recorded, When the grafted cups was completely sealed the queen cups were cut, placed in individual plastic vials and put in an electric incubator set at $32.0 \pm 0.2^{\circ} \mathrm{C}$ and $60-65 \% \mathrm{RH}$ (Dodologlu, 1995 and Dodologlu \& Genc 1997). The incubator checked every 4 - 5 hours for sorting newly emerged queens.

The resulted data was subjected to analysis of variance (ANOVA) and the means were compared by L.S.D. test at 0.05 level, using Duncan multiple rang test (Duncan, 1955).

\section{RESULTS AND DISCUSSION}

\section{1- Effect of rearing the season on virgin queen production}

As shown in Table (1) markedly difference was noticed between the mean number of virgin queens produced by single and double grafting methods, in addition, highly significant difference was found between the two methods of grafting, specially in Spring and Autumn seasons. 43.77 accepted cells were recorded in Spring season when we used single grafting was used, while it was 49.85 in double grafting, with increasing of the number of emerged virgin queens, the mean numbers were 37.66 and 47.07 emerged queens were for single and double grafting in Spring season, respectively. According to Mohanna \& Abd-Ellatif (1981); Ruttner, (1983) and Rice, (1994) some of queen producers have a capacity of more than 10,000 queens per year. This may be due to good climate conditions, good beekeepers and superior quality of healthy bees. Concerning the other seasons, no significant difference was between the two methods of grafting in summer and winter seasons, however, Spring was the best season for successful rearing followed by autumn and summer seasons, and winter was the worst. The mean number of emerged queens decreased till reached approximately $33 \%$ (20.44 queen from 60 grafted cell cups) after using single grafting, while it was $21.74 \%$ in case of double grafting. These findings indicate that, during the winter trials, queen cells were constructed in the central cell cups of the frame, but in both spring and Autumn it increased in the frame edge. Gloria et al (1993) mentioned that the worker honeybee in queen-less colonies constructed emergency queen cell on the periph- ery of the brood area on a comb when ambient temperature was high and in the center of the comb at low ambient temperature.

The present results are in agreement with those reported by El-Sarrag, (1993) who stated that, queens were successfully reared in February (92\%) and during March - June (82\%), and decreased sharply during August - September (48\%) to reach the minimum (28\%) during December January.

Considering the effect of grafting methods on queen production, it was obvious that, removing queen periods (queen-less) and larval ages at grafting played a main role in successful queen rearing.

As shown in Table (1), highly significant difference noticed between the mean number of emerged virgin queens when queens were removed 12, 24 and $48 \mathrm{hrs}$. before starting the experiment, being 31.61, 45.94 and 49.55 queens in spring, respectively. The corresponding numbers in Winter were 19.44, 22.27 and 21.55 respectively.

While the larva age show significant difference was found between the number of emerged queens produced from grafted 1,2 and 3 days old worker larvae, being 46.11, 44.66 and 36.33 queens in spring respectively. This means that, the workers preferred the youngest larvae to feed them with royal jelly.

It from the fore-mentioned results, could be concluded that, the best method for grafting was the, double grafting, using (one day old larvae for grafting), after removing the queens from the hive $48 \mathrm{~h}$. before starting the experiment. According to the obtained results from this experiment, the spring was found to be the season for queen rearing.

\section{B) Effect of cell cups frame locates in the hive on virgin queens production}

Data given in Table (2) showed the mean numbers of emerged queens in the three locations side the hive (near the entrance, center of the hive and in the side other of the entrance). Means of 17.6, 15.8 and 11.4 emerged queens from 20 grafted larvae were recorded after using double grafting and fitted the cups on the top bar, respectively. While there were 14.4 emerged queens were for recorded in case of single grafting and fitted on the center bar near side from hive entrance and 15.4 emerged queens for double grafting and fitted on the bottom bar when the frame 
Table 1. Number of accepted queen cells and number of emerged queens as being effected by grafting methods, period of removed queens before grafting and larval age at grafting

\begin{tabular}{|c|c|c|c|c|c|c|c|c|c|}
\hline \multirow{3}{*}{\multicolumn{2}{|c|}{ Treatments }} & \multicolumn{8}{|c|}{ Rearing season } \\
\hline & & \multicolumn{2}{|c|}{ Autumn } & \multicolumn{2}{|c|}{ Winter } & \multicolumn{2}{|c|}{ Spring } & \multicolumn{2}{|c|}{ Summer } \\
\hline & & $A C$ & QE & AC & QE & $A C$ & QE & AC & QE \\
\hline \multirow{3}{*}{ Grafting methods } & Single & 41.03 & 36.48 & 27.96 & 20.44 & 43.77 & 37.66 & 36.11 & 27.48 \\
\hline & Double & 34.81 & 39.62 & 26.55 & 21.74 & 49.85 & 47.07 & 35.88 & 28.74 \\
\hline & L.S.D. & - & $2.14^{* *}$ & - & NS & - & $2.54^{* * *}$ & - & NS \\
\hline \multirow{4}{*}{$\begin{array}{l}\text { Removal queen } \\
\text { period before } \\
\text { grafting (hours) }\end{array}$} & 12 & 36.33 & 32.33 & 25.11 & 19.44 & 37.72 & 31.61 & 32.88 & 24.11 \\
\hline & 24 & 45.16 & 41.11 & 27.33 & 22.27 & 49.61 & 45.94 & 37.16 & 30.72 \\
\hline & 48 & 45.77 & 40.72 & 28.77 & 21.55 & 53.11 & 49.55 & 37.44 & 29.50 \\
\hline & L.S.D. & & $2.63^{* * *}$ & - & NS & - & $3.11^{* *+*}$ & - & $3.57^{* *}$ \\
\hline \multirow{4}{*}{$\begin{array}{l}\text { Larvae age at } \\
\text { grafting (days) }\end{array}$} & 1 & 43.44 & 39.66 & 30.77 & 24.11 & 49.00 & 46.11 & 36.55 & 29.94 \\
\hline & 2 & 44.05 & 38.83 & 27.61 & 20.61 & 49.38 & 44.66 & 36.38 & 28.16 \\
\hline & 3 & 39.77 & 35.66 & 23.38 & 18.55 & 42.05 & 36.33 & 34.55 & 26.22 \\
\hline & L.S.D. & - & $2.63^{* *}$ & - & $4.32^{*}$ & - & $3.11^{* * *}$ & - & NS \\
\hline
\end{tabular}

AC, mean numbers of accepted cell cups

$Q E$, mean numbers of queens emerged

Table 2. Number of accepted queen sells and number of emerged queens as being affected by grafting methods and location of cell cup frame inside the hive

\begin{tabular}{|c|c|c|c|c|c|c|c|}
\hline \multirow{3}{*}{ Grafting methods } & \multicolumn{6}{|c|}{ Location of cell cup frame in side the hive } & \multirow{3}{*}{$\begin{array}{l}\text { L.S.D. } \\
(5 \%)\end{array}$} \\
\hline & \multicolumn{2}{|c|}{$\begin{array}{l}\text { Near hive } \\
\text { entrance }\end{array}$} & \multicolumn{2}{|c|}{ Center of the hive } & \multicolumn{2}{|c|}{$\begin{array}{l}\text { On the other side of } \\
\text { hive entrance }\end{array}$} & \\
\hline & AC & QE & AC & QE & AC & QE & \\
\hline SGTB & 17.80 & 14.00 & 15.80 & 11.40 & 12.00 & 7.8 & 1.48 \\
\hline DGTB & 18.40 & 17.60 & 17.40 & 15.80 & 17.20 & 11.40 & 1.64 \\
\hline SGCB & 17.40 & 13.20 & 15.00 & 9.80 & 10.40 & 7.20 & 1.79 \\
\hline DGCB & 16.60 & 14.40 & 15.60 & 12.00 & 16.60 & 11.80 & NS \\
\hline SGBB & 17.40 & 12.20 & 10.60 & 9.80 & 9.20 & 6.60 & 1.98 \\
\hline DGBB & 16.00 & 12.80 & 18.00 & 15.40 & 12.20 & 9.00 & 2.17 \\
\hline L.S.D. (5\%) & - & 2.75 & - & 2.008 & - & 1.61 & - \\
\hline
\end{tabular}

$\mathrm{QE}=$ mean numbers of accepted cells. $\mathrm{QE}=$ mean numbers of queens emerged.

$S G T B=$ single grafting cups and fixed on the top bar.

DGTB= double grafting cups and fixed on the top bar.

$S G C B=$ single grafting cups and fixed on the center bar.

$\mathrm{DGCB}=$ double grafting cups and fixed on the center bar.

$S G B B=$ single grafting cups and fixed on the bottom bar.

DGBB= double grafting cups and fixed on the bottom bar. 
Table 3. Effect of the cell cups location on the bar of the frame on successful queens production

\begin{tabular}{|c|c|c|c|c|c|c|c|c|c|c|c|}
\hline \multirow{4}{*}{$\begin{array}{l}\text { Grafting } \\
\text { methods }\end{array}$} & \multicolumn{10}{|c|}{ Location of cell cups on the bar } & \multirow{4}{*}{$\begin{array}{c}\text { L.S.D. } \\
(5 \%)\end{array}$} \\
\hline & \multicolumn{4}{|c|}{ Front } & \multirow{2}{*}{\multicolumn{2}{|c|}{ Center }} & \multicolumn{4}{|c|}{ Back } & \\
\hline & \multicolumn{2}{|c|}{ Edge } & \multicolumn{2}{|c|}{ Near edge } & & & \multicolumn{2}{|c|}{ Near edge } & \multicolumn{2}{|c|}{ Edge } & \\
\hline & $\mathbf{A C}^{*}$ & $\mathbf{Q E}^{*}$ & $\mathbf{A C}^{*}$ & $\mathbf{Q E}^{*}$ & $\mathbf{A C}^{*}$ & $\mathbf{Q E}^{*}$ & $\mathbf{A} \mathbf{C}^{*}$ & $\mathbf{Q E}^{*}$ & $\mathbf{A} \mathbf{C}^{*}$ & $\mathbf{Q E}^{*}$ & \\
\hline SGTB & 3.00 & 2.20 & 3.00 & 2.40 & 2.80 & 2.00 & 2.60 & 2.20 & 2.00 & 1.20 & NS \\
\hline DGTB & 3.00 & 2.40 & 3.60 & 3.20 & 3.00 & 2.40 & 2.80 & 2.40 & 3.00 & 2.00 & 0.61 \\
\hline SGCB & 3.00 & 2.20 & 3.00 & 2.00 & 2.80 & 2.00 & 2.60 & 1.80 & 2.00 & 2.00 & NS \\
\hline DGCB & 2.80 & 2.40 & 2.80 & 2.20 & 3.20 & 2.20 & 2.80 & 2.00 & 2.60 & 2.00 & NS \\
\hline SGBB & 2.60 & 1.80 & 2.00 & 1.00 & 2.60 & 2.20 & 2.40 & 2.00 & 2.00 & 2.00 & 0.55 \\
\hline DGBB & 2.50 & 1.40 & 2.60 & 1.80 & 2.60 & 1.80 & 2.60 & 2.20 & 2.40 & 2.00 & 0.55 \\
\hline L.S.D. (5\%) & - & 0.65 & - & 0.63 & - & NS & - & NS & - & NS & - \\
\hline
\end{tabular}

* See detailed identifications under Table (2)

located in hive center. The difference between these wears proved to be statistically highly significant.

In general, the best method of queen rearing is that when double grafting is used and cell cups frame placed in the center of the hive (when cell cups fitted on top and bottom bar), being rearing and queens production, the mean numbers 15.8 and 15.4 virgin queens, respectively.

\section{C) Effect of the cell cups location on the bar of} the frame on successful queen production

Data presented in Table (3) showed insignificant difference between treatments when the cell cups fitted on the back edge, front back edge and the center of the bar, but the difference was significant when the cell cups fitted on the edge and near front edge of the bar. The mean numbers were 2.4 and 3.2 queens emerged from 4 grafted larvae when using double grafting method and fixed the bar on the top of the frame.

On the other hand, double grafting was recorded the highest numbers of emerged queens with consideration for place of cell cups bar on the frame.

Certainly, the present results indicate that the cell cups fitted on the edges of the bars was successfully reared when ambient temperature was high in Spring, but queen cells in the center of the hive's brood nest maintained at significantly higher temperatures and had a greater chance of emerging than queen cells located on the edge, these results agree with those obtained by Gloria et al (1993) who mentioned that, in the queen-less colonies, the workers constructed emergency queen cells in the center of the comb when temperature was low.

\section{REFERENCES}

Dodologlu, A. (1995). Characteristics of Queen Honey Bees (Apis mellifera L.) Raised in Erzurum Condition p. 40. M.Sc. Dissertation, College of Agriculture, Ataturk University, Erzurum.

Dodologlu, A. and F. Genc (1997). The effect of rearing and mating methods on some characteristic of queen honeybees (Apis mellifera L.) Tr. J. Vet. Anim. Sci., 21: 379-385.

Doolittle, G.M. (1888). Scientific queen rearing. Am. Bee J. (Hamilton, III), 22 pp.

Duncan, D.B. (1955). Multiple range and Multiple F- test. Biometrics 11 1:1 - 24.

El-Din, H.A.E.S. (1999). Biological and ecological studies on rearing honeybee (Apis mllifera L.) for commercial queens production. Honeybee Sci. 20(3): 127-130.

El-Sarrag, M.S.A. (1993). Studies of some factors affecting brood rearing Activity in honeybee colonies in the central of Saudi Arabian Journal of King Saudi Univ. Agric. Sci. 5(1): 97-108.

Genc, F.B. and Emsen, A. Dodologlu, (2005). Effects of rearing period grafting method on the queen bee rearing. J. Appl. Anim. Res. 27(1): 4548. 
Gloria, D.H.; S. Maria and H.M. Joseph, (1993). Role of thermoregulation by nestmates on the development time of honeybee (Hymenoptera : Apidae). Queens Ann. Entomol. Soc. Am. 86(2): 165172.

Haydak, M.H. (1943). Larval food and development of castes in the honeybee. J. Econ. Entomol. 36: 778-783.

Koc, A.U. and M. Karacaoglu, (2004). Effects of rearing on the quality of queen honeybees (Apis mellifera L.) raised under the conditions of Aegean Region. Mellifera 4(7): 2-5 \& 34- 37.

Mohanna, N.F. (1977). Pollen Substitute and Honey Production. p. 100. Ph.D. Thesis, Alex. Univ., Egypt.
Mohanna, N.F. and M.A. Abd-Ellatif (1981). A new method for mass rearing honeybee queens, A. mellifera L. Proc. $4^{\text {th }}$ Arab Pesticide Conf. Tanta Univ., Egypt, pp. 387-392.

Morse, R.A. (1994). Rearing Queen Honeybees. pp. 64-72. Bd. Wicwas Press; Cheshire, Ct; USA. Rice, N. (1994). Queens by the thousands. Beekeepers - Quarterly No. 39: 21-25.

Ruttner, F. (1983). Queen Rearing. pp. 36-135. Apimondia Publishing House, Bucharest.

Seeley, T.D. (1985). Honeybee Ecology. A study of adaptation in social life. In: Krebs J.R. and T. Clutton - Brock (eds.). Monographs in Behavior and Ecology. 201 pp. Princeton Univ., Press, Princeton, NJ. 